\title{
Boosting tendon repair: interplay of cells, growth factors and scaffold-free and gel- based carriers
}

\author{
Zexing Yan ${ }^{1}$, Heyong Yin ${ }^{1}$, Michael Nerlich', Christian G. Pfeifer ${ }^{1}$ and Denitsa Docheva ${ }^{1,2^{*}}$ (D)
}

\begin{abstract}
Background: Tendons are dense connective tissues and critical components for the integrity and function of the musculoskeletal system. Tendons connect bone to muscle and transmit forces on which locomotion entirely depends. Due to trauma, overuse and age-related degeneration, many people suffer from acute or chronic tendon injuries. Owing to their hypovascularity and hypocellularity, tendinopathies remain a substantial challenge for both clinicians and researchers. Surgical treatment includes suture or transplantation of autograft, allograft or xenograft, and these serve as the most common technique for rescuing tendon injuries. However, the therapeutic efficacies are limited by drawbacks including inevitable donor site morbidity, poor graft integration, adhesion formations and high rates of recurrent tearing. This review summarizes the literature of the past 10 y concerning scaffold-free and gel-based approaches for treating tendon injuries, with emphasis on specific advantages of such modes of application, as well as the obtained results regarding in vitro and in vivo tenogenesis.

Results: The search was focused on publications released after 2006 and 83 articles have been analysed. The main results are summarizing and discussing the clear advantages of scaffold-free and hydrogels carriers that can be functionalized with cells alone or in combination with growth factors.

Conclusion: The improved understanding of tissue resident adult stem cells has made a significant progress in recent years as well as strategies to steer their fate toward tendon lineage, with the help of growth factors, have been identified. The field of tendon tissue engineering is exploring diverse models spanning from hard scaffolds to gel-based and scaffold-free approaches seeking easier cell delivery and integration in the site of injury. Still, the field needs to consider a multifactorial approach that is based on the combination and fine-tuning of chemical and biomechanical stimuli. Taken together, tendon tissue engineering has now excellent foundations and enters the period of precision and translation to models with clinical relevance on which better treatment options of tendon injuries can be shaped up.
\end{abstract}

Keywords: Tendons, Tendon repair, Tendon tissue engineering, Adipose-derived mesenchymal stem cells, Bone marrowderived mesenchymal stem cells, Tendon stem progenitor cells, Scaffolds, Hydrogels, Scaffold-free carriers, Cell sheets

\section{Introduction}

Tendons, which connect bone to muscle, are a crucial part of the locomotion system (Aslan et al. 2008). Tendons transmit forces from muscle to bone (Nourissat et al. 2015) and are able to withstand high tension and

\footnotetext{
* Correspondence: denitsa.docheva@ukr.de

'Laboratory of Experimental Trauma Surgery, Department of Trauma Surgery, University Regensburg Medical Centre, Franz-Josef-Strauss-Allee 11, 93053 Regensburg, Germany

${ }^{2}$ Director of Experimental Trauma Surgery, Department of Trauma Surgery, University Regensburg Medical Centre, Franz-Josef-Strauss-Allee 11, 93053 Regensburg, Germany
}

store elastic energy which in turn makes movements more ergonomic (Docheva et al. 2015). Tendons are very hierarchically organized tissues containing tendonspecific fibroblastic cells named according to their maturation state as tendon stem/progenitor cells (TSPCs), tenoblasts or tenocytes, the latter being the most terminally differentiated cells (Docheva et al. 2015). The cells are embedded in a three-dimensional network of extracellular matrix (ECM) consisting predominantly of type I collagen, other collagens (such type III and V), proteoglycans, elastin and fibronectin (Andres and Murrell 2008; Sayegh et al. 2015). The whole tendon 
unit and the tendon sub-units are wrapped with epitenon and endotenon loose connective sheets, respectively. It has been suggested that these sheets contain stem/progenitor-like cells (Docheva et al. 2015; Wu et al. 2017).

Tendon injuries are very common in trauma and orthopaedic surgery. Tendon injuries affect great range of patients from young to elderly patients, from workers to professional athletes (Docheva et al. 2015). Tendon healing follows a typical wound-healing course: inflammatory phase, proliferative phase, and then a remodelling phase (Voleti et al. 2012). The first short phase is characterized by the infiltration of inflammatory cells like platelets, monocytes, macrophages and neutrophils which release chemotactic agents activating and attracting tendon cells from the injured ends and tendon sheets. During the proliferative phase, the tendon fibroblasts start to proliferate and create abundant ECM. In the remodelling phase, the collagen fibres become parallel to the muscle force direction which is critical for the gain in tendon biomechanical strength (Evans 2012). In general, tendons have limited ability to repair as the initially formed scar tissue has inferior biomechanical properties compared to the original tendon tissue and if improperly replaced or remodelled it can be the foundation of increased rates of reoccurring ruptures.

Due to the highlighted above functional limitations and high rates of re-injury of once rupture tendon, various surgical techniques including surgical suture, tendon autograft and allograft transfer for repairing tendon injuries have been already been vastly described (Oryan et al. 2014). However, the long-term clinical outcomes of surgical treatments are still not satisfactory. Thus, new and novel techniques need to be developed. The growing interest in non-operative and conservative treatment options, even for total tendon ruptures calls for new ways to initiate endogenous tissue repair by regenerative mechanisms. Tissue engineering is a promising alternative treatment for achieving complete recovery of ruptured tendons and in general, is based on the combination of reparative cells, growth factors and carriers (Fig. 1).

The aim of this review is to revise the recent literature about tendon tissue engineering with particular focus on two types of carriers, hydrogels and scaffold-free approaches. Since most reviews have focused on two of the three components of the tissue engineering approach, namely cell types and growth factors, the carriers (third component) have not often been the focus. Actually, the

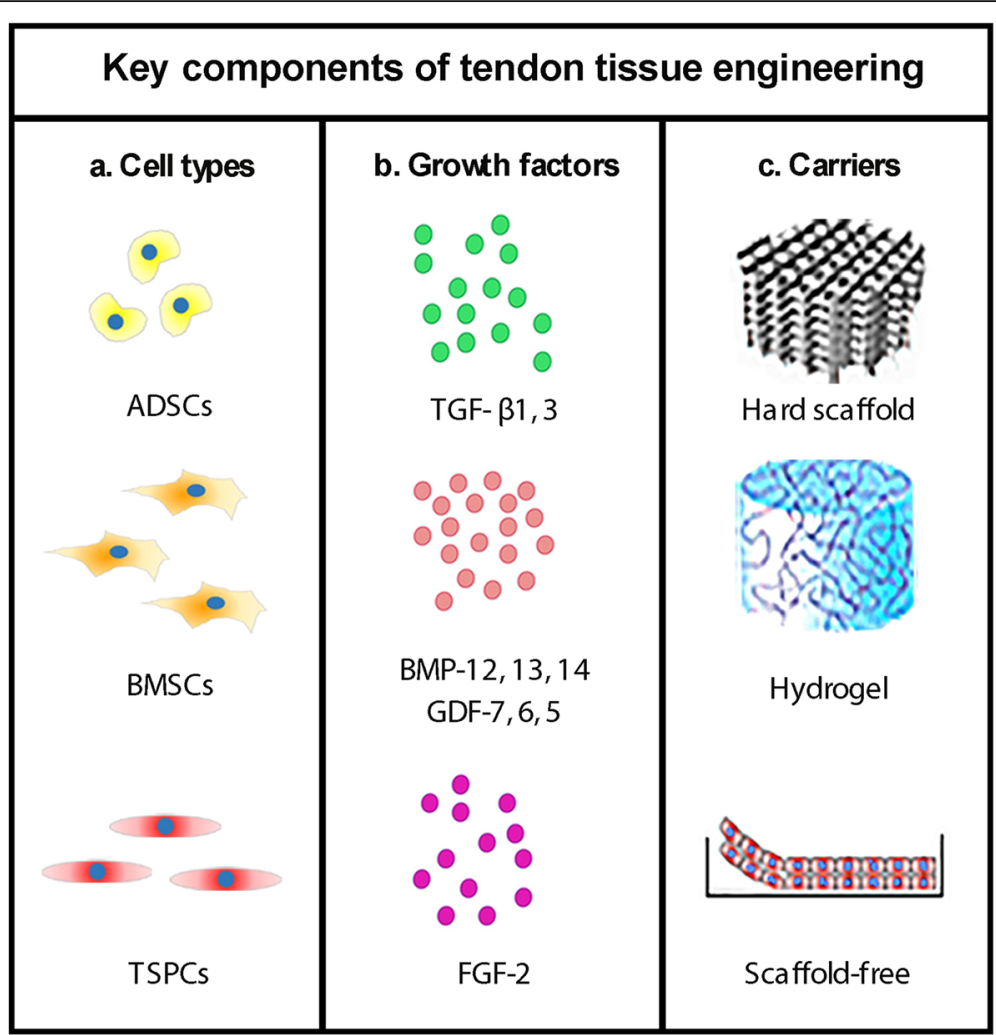

Fig. 1 Summary of the key components of tendon tissue engineering. a Favourable cell types; b Pro-tenogenic growth factors; c Possible scaffolds and self-assembled materials. Various combinations between the components are possible 
two types of carriers selected for evaluation in this review are particularly innovative and constitute a research field of increasing importance which can contribute to enhanced tendon tissue engineering.

The review constitutes of the following parts: (i) clinical relevance of tendon injury is provided; (ii) an overview of the areas involved in tendon tissue engineering (cells, growth factors, carriers) is given; (iii) the current status on cell types and growth factors is briefly summarized; and (iv) a detailed information on carriers with particular focus on hydrogels and scaffold-free options is delivered and discussed.

A computerized search of potentially eligible studies was performed in PubMed and the date of the last search was October 30, 2017. Database search and key inclusion criteria followed the terms "tendon" AND "tendon injury" AND "tendon repair" AND "tendon tissue engineering" AND "mesenchymal stem cells" AND "growth factors" AND "scaffold-free" OR "gelbased" OR "cell sheet". The search was focused to publications (both forms none- and open-access) released after 2006. Articles available only as abstract or not in English language or not fitting the review scope were excluded. A summary of the search strategy and article selection in this review is shown in Fig. 2.

\section{Review}

\section{Tendon clinical relevance}

Tendon injuries are usually induced by intrinsic (age, gender, weight, metabolic diseases) and extrinsic (sport injury, overload and occupation) factors. To date, treating tendon injuries costs healthcare providers in USA 30 billion dollars, and in Europe over 115 billion euros per year (Abbah et al. 2014). It is reported that $30-50 \%$ of sport injuries include tendon component (September et al. 2007). Epidemiologic reports indicate that annually over 4.4 million patient clinical visits in USA are due to shoulder maladies associated with tendon disorders (Nixon et al. 2012). Chronic and acute injuries can occur in any tendon, although, the most frequently affected tendons are Achilles and rotator cuff tendons. Raikin et al. 2013 reviewed that regarding Achilles tendon injuries $76 \%$ of the ruptures are acute with average patient age of 46.4 years, whereas $24 \%$ are chronic. Rotator cuff tears affect up to $50 \%$ of patients older than 50 years and are a common cause of function-limiting pain and weakness of the shoulder (Isaac et al. 2012). Tendon repair after injury is extremely poor and inefficient because of the low cellularity, vascularity and metabolic activity of the tendon tissue (Liu et al. 2011; Thangarajah et al. 2015). Moreover, in most patients, especially in aged individuals, the healed tendon usually does not regain the mechanical properties of the uninjured tissue. As a consequence, the tendon thickens and stiffens to overcome the lower unit mechanical strength and, hence, the tendon quality and its functional activity are inferior to that of healthy tendon (Docheva et al. 2015). For the above reasons identifying and designing strategies to augment tendon healing are of very high relevance. Over the years, the tendon scientific community has particularly focused on establishing and improving
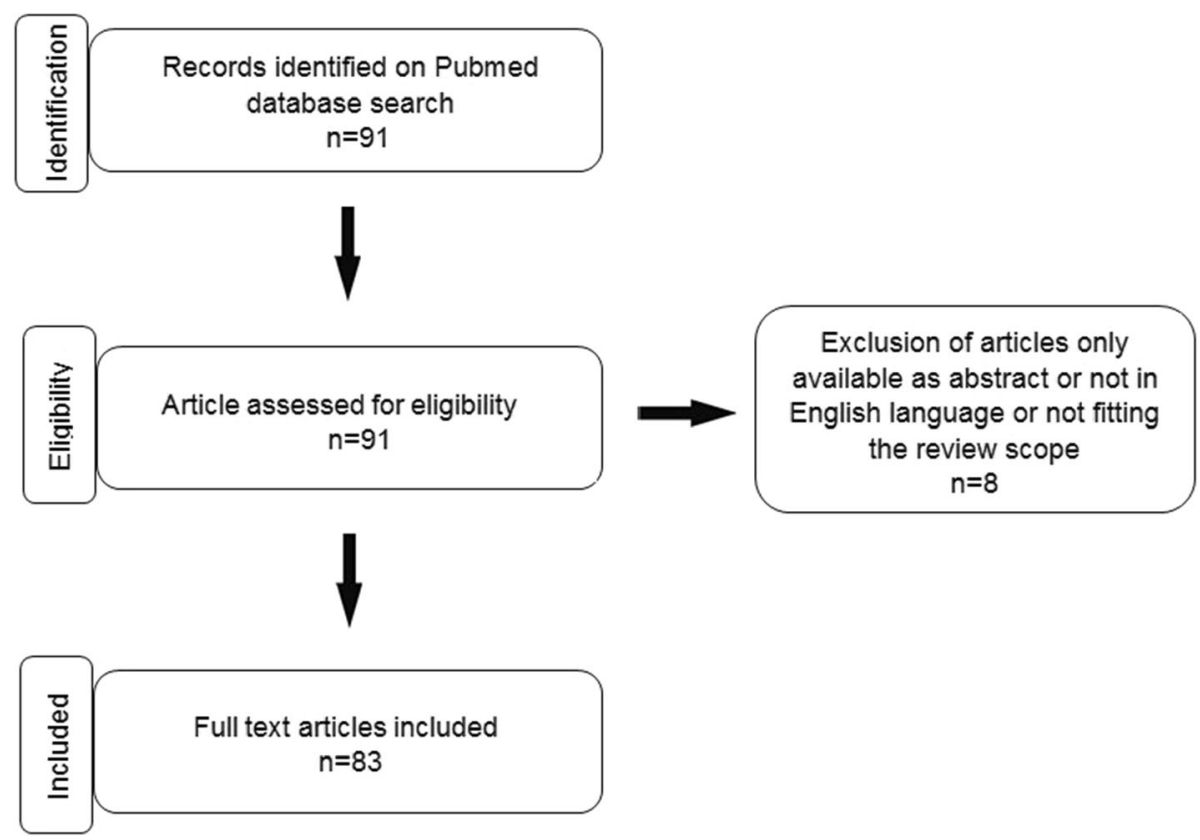

Fig. 2 Flow chart of the search strategy and article selection in this review 
various tendon tissue engineering models which become very promising for achieving a breakthrough in tendon injury management.

As previously mentioned, the most common strategy for restoring ruptured tendons is surgical repair which at times does not result in complete and satisfactory tendon healing. Especially in elderly individuals, surgical repair shows poor long-term outcomes due to re-rupture, restrictive adhesions and suboptimal strength and functionality linked to decreased biomechanical properties (Myer and Fowler 2016). Considerable side effects and complications are seen with operative treatment. In Achilles tendon repair, the majority of patients occur in men aged 30-49 and are reported due to wound and tendon healing problems, like re-rupture, tissue damage and necrosis and subsequently wound infection (Raikin et al. 2013; Thomopoulos et al. 2015). It has been known that several factors, including advanced patient age, large tear size, severe muscle atrophy and fatty infiltration, systemic metabolic diseases and smoking are associated with failed or poor tendon healing (Montgomery et al. 2012). Since traditional surgical options present limitations and complications, non-operative treatment has gained interest in recent years. The challenge of non-operative treatment is the diastasis of the ruptured tendon ends. Any gap and tendon defect may delay the healing process and may result in an insufficient tendinous tissue. Therefore, innovative treatment options such as tissue engineering of ruptured tendons has drawn great interest and driven multi-centre experimental and preclinical research to solve this issue.

\section{Tendon tissue engineering}

Tissue engineering aims to induce and support tissue self-repair or to produce a functional tissue replacement in vitro that is subsequently implanted in vivo at the site of injury (Youngstrom and Barrett 2016). Hence, tissue engineering may play a major role in improving the management of tendon injuries through grafting engineered tendon segment at the site of rupture (Hsieh et al. 2016b; Yin et al. 2016). We have previously reviewed in great detail (Docheva et al. 2015; Wu et al. 2017) on the two main components of tendon tissue engineering namely cell types and growth factors as well as given summary on the recent advancment of natural hard scaffolds. The current review focuses on the "third component", the carrier and in particular on hydrogels and scaffold-free approaches. A hydrogel is a network of natural or synthetic polymer chains with high content of liquid. Due to their significant water content, hydrogels are softer and easier to mould and therefore suitable as filling materials. On the other hand, scaffold-free approaches allow the cells to form natural cell to cell and cell to matrix connections without artificial interference and with firing of specific molecular signalling events that can trigger lineage mantainance or even facilitate further maturation.

\section{Cell types}

In tendon tissue engineering, mainly stem or progenitor cells of mesenchymal origin are being implemented to create tendon grafts and support graft incorporation (Andres and Murrell 2008). Several cell types have been more favourable and these belong to the mesenchymal stem cells family (MSCs) found in different tissue sources. MSCs extracted from adipose tissues or the bone marrow or tendon-derived cells, including local MSC-related but distinct TSPCs, have been suggested as the most suitable cell types (Yin et al. 2016). These cell types have clear advantages like differentiation potential as well as paracrine effects, which have been reported to play a crucial role in their beneficial properties, by promoting angiogenesis, stimulating local progenitor and mature cells, or regulating inflammation and immune cell functions (da Silva et al. 2009).

MSCs derived from adipose tissue (ADSCs) are an attractive candidate cell type due to their easy isolation, multi-potentiality and high responsiveness to distinct environment cues (Zarychta-Wisniewska et al. 2017). Adipose tissue is abundant in human and animals and subcutaneous adipose aspirate can be easily harvested by a minimally invasive procedure (Deng et al. 2014). However, the main disadvantage of ADSCs is their preference towards adipogenesis in vivo (Neo et al. 2016).

Bone marrow mesenchymal stem cells (BMSCs) due to being best characterized are the most widely used stem cell type. One recent study showed that BMSCs are more responsive to bone morphogenetic protein-12 (BMP-12) stimulation and hence exhibited superior tenogenic differentiation capacity when compared to ADSCs (Dai et al. 2015). However, BMSCs also have some limitations, such as painful harvesting procedure with frequently low cell yield, reduced MSC quality with advanced donor age (Zhao et al. 2009), ectopic ossification and higher risk of adhesion formation when transplanted in vivo (Hsieh et al. 2016a).

TSPCs are a cell type that moved in the research spotlight due to their inherent pro-tenogenic abilities. They were first reported and described in 2007(Bi et al. 2007) and subsequently identified in different tendons, isolated from different species and characterized to some extent (Kohler et al. 2013). One clear advantage of TSPCs is their greater potential for tenogenesis. TSPCs express higher mRNA levels of tendon-related gene markers including the transcription factor Scleraxis (Scx) and the late differentiation factor Tenomodulin (Tnmd) than BMSCs (Ni et al. 2013). Furthermore, we have recently shown in two consecutive studies that native or 
genetically induced TSPCs transplanted in clinically relevant Achilles tendon defect model in Rattus norvegicus are superior to BMSCs as TSPCs grafting resulted in advanced, significantly less ossified and more mature ECM of the tendon at the remodelling phase of the healing process (Yin et al. 2013). However, TSPCs hold one main disadvantage namely their isolation that is associated with many limitations and co-morbidity. One strategy to overcome this difficulty is to use ADSCs or BMSCs that have been pre-differentiated towards the tendon lineage with the help of growth factors, a topic we will discuss in the next chapter and in Table 1.

\section{Growth factors}

Growth factors play an important role in tendon tissue engineering. They are peptide signalling molecules with a dominant biological role in regulating cell proliferation and differentiation (Branford et al. 2014). Growth factors relevant to the tendon healing process and MSC tenogenesis include families such as bone morphogenetic protein (BMP) family, fibroblast growth factor (FGF), transforming growth factor beta (TGF- $\beta$ ), insulin-like growth factor (IGF), vascular endothelial growth factor (VEGF), connective tissue growth factor (CTGF) and platelet-derived growth factor (PDGF). Many studies have shown that MSCs are very sensitive to the above factors and they can influence their stemness and steer the rate of proliferation and extent of terminal differentiation (Barsby et al. 2014; Halper 2014; Han et al. 2017; Jiang et al. 2016; Lui et al. 2016; Park et al. 2010; Tan et al. 2012; Tokunaga et al. 2015; Violini et al. 2009; Zarychta-Wisniewska et al. 2017). However, only some of the growth factors have promising effects on MSC tenogenesis and example studies and their outcomes are described in Table 1.

Growth factor stimulation protocols of MSCs to achieve tenogenesis in vitro are advancing, However, in order to become very efficient and reproducible, further research understanding the exact molecular signalling events orchestrating and controlling the step-wise commitment process is required. In this respect, great knowledge can be obtained from tendon developmental studies based on gene knockout and reporter mouse strains (Dex et al. 2016). Another research area that can lead to accelerated tenogenesis is applying mechanical loading in combination with growth factors (James et al. 2008).

\section{Carriers}

\section{Hard scaffolds}

Scaffolds are used to deliver cells and drugs into the body (Garg et al. 2012; Turner and Badylak 2013). Classically, scaffolds are made of hard materials displaying distinct architecture, porosity, interconnectivity, large surface and biocompatibility. The current materials used in tendon tissue engineering have provided significant advances in structural integrity and biological compatibility and in many cases the results are superior to those observed in natural healing (Butler et al. 2008; Liu et al. 2008; Sahoo et al. 2010b). Several kinds of scaffolds have been widely used in tendon tissue engineering such as biologically-based or synthetic scaffolds (Youngstrom and Barrett 2016). Biological scaffolds which includes dermis, pericardium, small intestine submucosa, and tendon, are composed of natural collagen fibres that are bioactive and beneficial for cell attachment, viability and proliferation (Woon et al. 2011). The structure of biological scaffolds may better resemble the original tissue and be more feasible for incorporating and supporting cells but they could be more difficult to obtain and might require additional and more complicated surgery in order to be delivered into the site of injury. In addition, to avoid in vivo immunoreaction, biological scaffolds need to be decellularized prior to implantation. Furthermore, another widely used scaffold type is silk, which has been shown to perform well both in vitro and in vivo tendon studies (Chen et al. 2010). Some other natural materials e.g. human umbilical veins and hyaluronic acid-based scaffolds have been also explored and given promising results in tendon tissue engineering (Fan et al. 2014; Hofmann et al. 2008).

Synthetic scaffolds made from polymers, such as polylactic acid (PLA); poly-L-lactid acid (PLLA); polyglycolic acid (PGA); poly-D,L-lactic-co-glycolic acid (PLGA); polyuria (PU) and poly-caprolactone (PCL), aim at mimicking the native tissue properties and are frequently produced by electrospinning technology (Sahoo et al. 2010b; Sahoo et al. 2010c). TSPCs cultivated on electrospun nanofibers showed augmented tenogenic gene expression (Yin et al. 2010) and increased ECM production (Xu et al. 2014). Some scaffolds are comprised of orientated nano/microfibers which results in similar structure to the native tendon tissue, hence enabling the typical spindle morphology of tendon cells and providing structural cues for tenogenesis (Sahoo et al. 2010). However, traditional hard scaffolds have limitations including poor cell seeding and distribution, low cell adhesion especially onto synthetic materials, unsatisfactory cell proliferation and differentiation and in some cases poor biocompatibility, low biodegradability, and non-matching to the tendon biomechanical properties (Liu et al. 2008; Lui et al. 2014; Ricchetti et al. 2012). The main difficulty arises from the structural and biomechanical properties of the materials and the creation of continuity when implanted in vivo. Research has suggested that materials resembling the hierarchical ECM organisation and dimensions, as well as the elastic properties of tendon tissues are preferable (Bagnaninchi et al. 
Table 1 Pro-tenogenic growth factors

\begin{tabular}{|c|c|c|c|}
\hline Growth factor & $\begin{array}{l}\text { Cell } \\
\text { source }\end{array}$ & $\begin{array}{l}\text { Cell proliferation } \\
\text { and differentiation }\end{array}$ & Gene expression \\
\hline $\begin{array}{l}\text { TGF- } \beta 1 \\
(5 \mathrm{ng} / \mathrm{ml}) \\
\& \text { TNF-a } \\
(0.0025 \mathrm{ng} / \mathrm{ml})\end{array}$ & $\begin{array}{l}\text { Rat } \\
\text { TSPCS }\end{array}$ & $\begin{array}{l}\text { TGF- } \beta 1 \text { or TNF- } a \text { alone did not } \\
\text { enhance the proliferation and } \\
\text { differentiation of TSPCs, but in } \\
\text { combination or upon sequential } \\
\text { application of these two signalling } \\
\text { molecules facilitated their } \\
\text { proliferation and differentiation. } \\
\text { Furthermore the combined } \\
\text { application of TGF- } \beta 1 \text { in addition } \\
\text { to TNF-a could resque the growth } \\
\text { inhibition induced by TNF-a. }\end{array}$ & $\begin{array}{l}\text { TGF- } \beta \text { signalling pathway } \\
\text { significantly activated the } \\
\text { expression levels of certain } \\
\text { members of Smad family. In } \\
\text { addition, the expression of } \\
\text { tenogenic/osteogenic markers } \\
\text { was also significantly increased } \\
\text { under the combined treatment } \\
\text { of TGF- } \beta 1 \text { and TNF- } a\end{array}$ \\
\hline $\begin{array}{l}\text { TGF- } \beta 3 \\
(20 \mathrm{ng} / \mathrm{ml})\end{array}$ & $\begin{array}{l}\text { Equine } \\
\text { embryo- } \\
\text { derived } \\
\text { SCs } \\
\text { (ESCs) }\end{array}$ & $\begin{array}{l}\text { TGF- } \beta 3 \text { can promote tenocyte } \\
\text { differentiation of ESCs in } 2 D \\
\text { monolayer cultures. The ESCS } \\
\text { did not develop areas of } \\
\text { cartilage or bone tissue, and it } \\
\text { was concluded that the } \\
\text { differentiation response is } \\
\text { specific to tenogenic lineage. }\end{array}$ & $\begin{array}{l}\text { Express tendon-associated } \\
\text { genes were detected. The } \\
\text { presence of TGF- } \beta 3 \text { induced } \\
\text { the expression of late-onset } \\
\text { tenogenic markers, namely } \\
\text { Tnmd and thrombospondin 4, } \\
\text { which were not detected in } \\
\text { untreated cultures over the } \\
\text { early time course. }\end{array}$ \\
\hline $\begin{array}{l}\text { GDF-5 } \\
(\text { BMP-14) } \\
(100 \mathrm{ng} / \mathrm{ml})\end{array}$ & $\begin{array}{l}\text { Rat } \\
\text { ADSCs }\end{array}$ & $\begin{array}{l}\text { GDF-5 led to increased ADSCs } \\
\text { proliferation in a dose- and } \\
\text { time-dependent manner. In } \\
\text { the time kinetic studies, the } \\
\text { proliferation rate of ADSCs } \\
\text { treated with } 100 \mathrm{ng} / \mathrm{ml} \text { of } \\
\text { GDF-5 increased significantly } \\
\text { at all time points. }\end{array}$ & $\begin{array}{l}\text { ADSCs demonstrated } \\
\text { enhanced ECM production } \\
\text { and tenogenic marker gene } \\
\text { expression that was increased } \\
\text { with longer exposure. GDF-5 } \\
\text { also altered the expression of } \\
\text { ECM remodelling genes, with } \\
\text { no specific dose and time } \\
\text { trends observed. The two } \\
\text { key tenogenic markers Scx } \\
\text { and Tnmd showed clear } \\
\text { upregulation with } 100 \mathrm{ng} / \mathrm{ml} \\
\text { GDF-5. }\end{array}$ \\
\hline
\end{tabular}
tenogenic differentiation of this

The tenogenic marker genes Scx and TnC were upregulated at day 4 after GDF-5 treatment. However, at day 7, only Scx
GDF-5

(BMP-14)

$(0,5,25,50$,

$100 \mathrm{ng} / \mathrm{ml})$

\section{Human GDF-5 did not alter the} BMSCs proliferation rate significantly. The use of GDF-5 induced cell type without effect on cell doubling. It appears that GDF-5 at a concentration of $100 \mathrm{ng} / \mathrm{ml}$ provides the most optimal cell phenotypic response.

$\begin{array}{ll}\text { GDF-6 } & \text { Rabbit } \\ \text { (BMP-13) } & \text { BMSCs } \\ \text { (20 ng/ml) } & \end{array}$

(20 $\mathrm{ng} / \mathrm{ml})$

GDF-7

(BMP-12)

(50 $\mathrm{ng} / \mathrm{ml})$
Equine Cell proliferation was not studied BMSCs; Equine BMSCs defined by their in vitro expression of markers such as Oct4, Sox-2 and Nanog, have the capability to differentiate in tenocytes based on gene expression.

$\begin{array}{lll}\text { ECM production } & \begin{array}{l}\text { Study type } \\ \text { and animal } \\ \text { model }\end{array} & \text { Reference } \\ \text { Not studied } & \text { In vitro } & \begin{array}{l}\text { Han } \\ \text { et al. 2017 }\end{array}\end{array}$

ESCs treated with TGF- $\beta 3$

In vitro

Barsby organized a tendon-like matrix without evidence of bone or cartilage formation.

Col I expression increased in cells treated with $100 \mathrm{ng} / \mathrm{ml}$ of GDF-5 compared to control. In vitro Park No significant difference was found for Col III. was persistently upregulated, the expression of Runx 2 and Sox9 genes were significantly downregulated. In conclusion this growth factor augmented the levels tenogenic marker genes and downregulated non-tenogenic marker gene expression.

Expression of Scx and Tnmd was significantly higher under GDF-6 stimulation. Expression levels of $\mathrm{TnC}$ and $\mathrm{Col} I$ were higher in the control group but not significant.

Following exposure to BMP-12 the BMSCs upregulated the ex pression of two tendon-related

Violini et al. 2009
Tan

et al. 2012
Histological evaluation of patellar tendon injury repair model suggested that transplantation of GDF-6treated BMSCs improved ten don healing due to increase Col deposition and presence of more organized Col fibers. Not studied.

deposition between GDF-5

concentration levels. However augmented the total collagen amount.

model

In vitro 
Table 1 Pro-tenogenic growth factors (Continued)

\begin{tabular}{|c|c|c|c|c|c|c|}
\hline Growth factor & $\begin{array}{l}\text { Cell } \\
\text { source }\end{array}$ & $\begin{array}{l}\text { Cell proliferation } \\
\text { and differentiation }\end{array}$ & Gene expression & ECM production & $\begin{array}{l}\text { Study type } \\
\text { and animal } \\
\text { model }\end{array}$ & Reference \\
\hline $\begin{array}{l}\text { BMP-12 } \\
\text { (GDF-7) } \\
\text { (50 or } \\
100 \text { ng/) }\end{array}$ & $\begin{array}{l}\text { Human } \\
\text { ADSCs; } \\
\text { in vitro }\end{array}$ & $\begin{array}{l}\text { There was no significant } \\
\text { difference in proliferation rates } \\
\text { of ADSCs after treatment with } \\
\text { BMP-12, regardless of the } \\
\text { applied doses. BMP-12 activated } \\
\text { tenogenesis of ADSCs based } \\
\text { on gene expression analyses. }\end{array}$ & $\begin{array}{l}\text { ADSCs treated with BMP-12 } \\
\text { for } 7 \text { days resulted in } \\
\text { up-regulation of tenogeinic } \\
\text { genes, such as Scx and } \\
\text { Mohawk but also Runx2, an } \\
\text { osteogenic maker gene was } \\
\text { elevated. }\end{array}$ & $\begin{array}{l}\text { BMP-12 treatment increased } \\
\text { expression of } \mathrm{Col} I \text { in ADSCs. }\end{array}$ & In vitro & $\begin{array}{l}\text { Zarychta- } \\
\text { Wisniewska } \\
\text { et al. } 2017\end{array}$ \\
\hline $\begin{array}{l}\text { FGF-2 } \\
(5 \mu \mathrm{g} / \mathrm{ml})\end{array}$ & $\begin{array}{l}\text { Rat } \\
\text { TSPCS }\end{array}$ & $\begin{array}{l}\text { In vivo evaluation at } 2 \text { and } \\
4 \text { weeks post-operation showed } \\
\text { that the FGF-2-treated group } \\
\text { has greater numbers of cells in } \\
\text { the granulation tissue than the } \\
\text { control group. At } 6 \text { weeks } \\
\text { there was no significant } \\
\text { difference in cell number } \\
\text { between the FGF-2-treated } \\
\text { group and the control group. }\end{array}$ & $\begin{array}{l}\text { The expression level of Scx } \\
\text { increased in the FGF-2-treated } \\
\text { group from } 4 \text { to } 8 \text { weeks, } \\
\text { and Tnmd levels increased } \\
\text { significantly from } 4 \text { to } \\
12 \text { weeks postoperatively. } \\
\text { Sox } 9 \text { expression was } \\
\text { significantly up-regulated at } \\
4 \text { weeks in the FGF-2-treated } \\
\text { group. }\end{array}$ & Not studied. & $\begin{array}{l}\text { In vivo; rat } \\
\text { rotator cuff } \\
\text { healing } \\
\text { model }\end{array}$ & $\begin{array}{l}\text { Tokunaga } \\
\text { et al. } 2015\end{array}$ \\
\hline
\end{tabular}

2007). Forthcoming studies should focus on investigating their further optimization and long-term behaviour in clinically relevant models of tendon injury.

\section{Hydrogels}

As mentioned previously hydrogels are a network of natural or synthetic polymer chains with significant water content, possessing a higher degree of moulding. They are commonly used in tissue engineering because of their easier handling and good biocompatibility (Yamada et al. 2007). Hydrogels can fill up various defect shapes and can reach deeper into tissue injury site by percutaneous injection with minimal invasion and low side effects which normally occur after more complicated surgery techniques when hard scaffolds are used. Furthermore, hydrogels can incorporate various cells, drugs, and growth factors through simple mixing. Adherent cells can deposit in their vicinities, natural ECM and organise it appropriately and create a niche that responds to chemical and biomechanical stimuli. Hydrogels composed of natural biomaterials such as collagen, fibrin, hyaluronic acid, alginate, and other ECM proteins are most frequently used. In Table 2, we have summarized studies which focused on the application of hydrogels functionalized with cells for tendon tissue engineering. Most of the studies have investigated how such hydrogels affect the biological features of MSCs and tendon-derived cells in vitro (Annabi et al. 2014; Bian et al. 2013). Only few studies have tested the repair potential of hydrogels alone or in combination with cells in tendon injury models in vivo (Liu et al. 2008; Shah and Federoff 2011). Type I collagen and fibrin gels have been extensively studied to create tissue engineering constructs in vitro (Sander et al. 2011). Breidenbach et al. showed that fibrin gels loaded with TSPCs exhibit improved biological, structural, and mechanical characteristics compared with TSPCs-collagen gels in vitro (Breidenbach et al. 2015). Degen et al., Li et al., and Lopiz et al. reported that the application of hyaluronic acid or alginate hydrogels resulted in enhanced biomechanical and histological properties of the tendon repair tissue in vivo compared with control groups (Degen et al. 2016; Li et al. 2016; Lopiz et al. 2017). Farnebo et al., 2014 developed a novel injectable thermosensitive hydrogel derived from tendon ECM and seeded it with ADSCs (Farnebo et al. 2014). It formed a solid gel at body temperature and had good compatibility and support of cell adhesion and proliferation. Chiou et al., 2015 showed that the hydrogels combined with ADSCs augmented the tendon healing process in a rat injury model (Chiou et al. 2015). The above studies indicated that hydrogels hold a great potential for tissue engineering as they can provide a three-dimensional environment and can serve as an easier to handle cell delivery vehicle for surgical implantation. Despite several advantages and some promising experimental outcomes of the gel-based tissue engineering approach, one very critical limitation especially with regards to tendon repair is that the hydrogels cannot provide in a full tear scenario, the desired biomechanical strength and tissue continuity. Hence, their application can be specialized for cell or drug delivery in partial tendon lesions, contained tendon defects or underneath tendon sheets (Garg et al. 2012).

\section{Scaffold-free approaches}

A scaffold-free approach means that cell form naturally the connections between each other and the matrix, thus tendon tissue engineered construct can be fabricated without the use of any carrier (Ni et al. 2013). With 
Table 2 Hydrogel-based studies on tendon tissue engineering

\begin{tabular}{|c|c|c|c|c|c|c|}
\hline Hydrogel & Cell type & Cell proliferation and vitality & Gene expression and ECM & Biomechanical analyses & $\begin{array}{l}\text { Study type, } \\
\text { animal species } \\
\text { and delivery } \\
\text { method }\end{array}$ & Reference \\
\hline $\begin{array}{l}\text { Collagen/ } \\
\text { Fibrin }\end{array}$ & TSPCS & Not studied & $\begin{array}{l}\text { TSPCs in the fibrin hydrogel } \\
\text { exhibited significant } \\
\text { upregulation of tenogenic } \\
\text { markers (Scx, TnC, and F-mod) } \\
\text { in comparison to Col gel. Tissue } \\
\text { engineering constructs based } \\
\text { on fibrin with TSPCs showed } \\
\text { better collagen alignment } \\
\text { compared to Col hydrogel. }\end{array}$ & $\begin{array}{l}\text { Tissue engineered construct } \\
\text { based on fibrin hydrogel } \\
\text { showed higher linear stiffness } \\
\text { than Col gel at day } 10 \text {. However, } \\
\text { no significant difference was } \\
\text { detected at day } 14 \text {. }\end{array}$ & In vitro & $\begin{array}{l}\text { Breidenbach } \\
\text { et al. } 2015\end{array}$ \\
\hline Fibrin & BMSCs & $\begin{array}{l}\text { Over } 90 \% \text { of labeled BMSCs } \\
\text { remained viable after mixing } \\
\text { in the fibrin hydrogel. }\end{array}$ & $\begin{array}{l}\text { BMSCs continued to express } \\
\text { the original phenotypic profile. } \\
\text { Notably, all cells showed an } \\
\text { absence of CD14, CD34, and } \\
\text { CD45 expression. In addition, } \\
\text { they maintained expression of } \\
\text { CD105, CD73, and CD90. }\end{array}$ & $\begin{array}{l}\text { At } 2 \text { weeks, there was a } \\
\text { significant increase in stiffness } \\
\text { of repaired tissue in the cell- } \\
\text { treated group compared with } \\
\text { the control group. However, at } \\
4 \text { weeks, this effect dissipated } \\
\text { because both groups showed } \\
\text { similar stiffness. }\end{array}$ & $\begin{array}{l}\text { Athymic rat; } \\
\text { Surgery }\end{array}$ & $\begin{array}{l}\text { Degen et al. } \\
2016\end{array}$ \\
\hline Fibrin & TSPCS & $\begin{array}{l}\text { The cell proliferation rate in the } \\
\text { TSPCs group treated with CTGF } \\
\text { and ascorbic acid was lower } \\
\text { compared with control group. }\end{array}$ & Not studied. & $\begin{array}{l}\text { The transplantation of TSPC- } \\
\text { fibrin constructs promoted } \\
\text { tendon repair up to week 16, } \\
\text { while TSPC that were pre- } \\
\text { treated with CTGF showed } \\
\text { better results already at } 8 \text {. Both } \\
\text { the ultimate stress and } \\
\text { maximum Young's modulus } \\
\text { increased at a faster rate in the } \\
\text { CTGF- treated TSPC group } \\
\text { compared with the untreated } \\
\text { group. }\end{array}$ & $\begin{array}{l}\text { In vitro; Rat; } \\
\text { Surgery }\end{array}$ & $\begin{array}{l}\text { Lui et al. } \\
2016\end{array}$ \\
\hline HA & $\begin{array}{l}\text { Tendon } \\
\text { fibroblasts }\end{array}$ & $\begin{array}{l}\text { HA significantly decreased } \\
\text { cell proliferation in a } \\
\text { dose-dependent manner. }\end{array}$ & $\begin{array}{l}\text { Immunofluorescence } \\
\text { cytochemistry detected } \\
\text { constitutive binding of HA and } \\
\text { CD44 receptor on the tendon- } \\
\text { derived cells. The expression } \\
\text { levels of pro-collagen I a1 was } \\
\text { not significantly decreased, but, } \\
\text { the expression of procollagen III } \\
\text { a1 was decreased significantly } \\
\text { in a dose-dependent manner. }\end{array}$ & Not studied. & In vitro & $\begin{array}{l}\text { Yamada et } \\
\text { al. } 2007\end{array}$ \\
\hline $\begin{array}{l}\text { Tendon } \\
\text { ECM }\end{array}$ & ADSCS & $\begin{array}{l}\text { Spindle shaped cells were } \\
\text { observed both on the gel } \\
\text { surface as well as within the } \\
\text { gels, with a homogenous } \\
\text { distribution of cells } \\
\text { throughout the gel. }\end{array}$ & $\begin{array}{l}\text { Gene expression was not } \\
\text { studied. This ECM gel solution } \\
\text { can be delivered percutaneously } \\
\text { into the zone of tendon injury } \\
\text { in a rat model. After injection, } \\
\text { the thermos-responsive behav } \\
\text { iour of the ECM solution will } \\
\text { allow it to gelate at body } \\
\text { temperature. A supportive } \\
\text { nanostructure of collagen } \\
\text { fibres can be established to fit } \\
\text { the three-dimensional space of } \\
\text { the defect. }\end{array}$ & Not studied. & Rat; Injection & $\begin{array}{l}\text { Farnebo et } \\
\text { al. } 2014\end{array}$ \\
\hline $\begin{array}{l}\text { Tendon } \\
\text { ECM }\end{array}$ & ADSCS & $\begin{array}{l}\text { Proliferation rate of ADSC in } \\
\text { tendon ECM-derived hydrogel } \\
\text { treated with PRP was higher } \\
\text { than untreated group. }\end{array}$ & $\begin{array}{l}\text { Gene expression was not } \\
\text { studied. Upon histological } \\
\text { analysis, Hematoxylin and } \\
\text { Eosin staining showed } \\
\text { increased extracellular matrix } \\
\text { formation in groups } \\
\text { containing PRP and increased } \\
\text { cellularity in groups } \\
\text { containing ADSCs. }\end{array}$ & $\begin{array}{l}\text { Mean ultimate failure load was } \\
\text { increased in hydrogels } \\
\text { augmented with PRP group at } \\
2 \text { weeks. At } 4 \text { weeks, hydrogel } \\
\text { alone reached a similar mean } \\
\text { ultimate failure load to } \\
\text { hydrogels augmented with } \\
\text { PRP and ADSCs. However, at } \\
8 \text { weeks, hydrogels with PRP } \\
\text { and ADSCs demonstrated }\end{array}$ & Rat; Surgery & $\begin{array}{l}\text { Chiou et al. } \\
2015\end{array}$ \\
\hline
\end{tabular}


Table 2 Hydrogel-based studies on tendon tissue engineering (Continued)

\begin{tabular}{|c|c|c|c|c|c|c|}
\hline Hydrogel & Cell type & Cell proliferation and vitality & Gene expression and ECM & Biomechanical analyses & $\begin{array}{l}\text { Study type, } \\
\text { animal species } \\
\text { and delivery } \\
\text { method }\end{array}$ & Reference \\
\hline & & & & $\begin{array}{l}\text { increased strength over } \\
\text { other groups. In conclusion, } \\
\text { groups containing both PRP } \\
\text { and ASCs encouraged } \\
\text { earlier mechanical strength } \\
\text { and functional restoration. }\end{array}$ & & \\
\hline
\end{tabular}

additional growth factors or mechanical stimuli, the cells can enhance the tenogenic differentiation process as well as the production of tendon-specific extracellular matrix (Kim et al. 2011). As human embryos can organize, proliferate and differentiate within itself without association to a scaffold so tendon tissue can be formed by a selfassembly process. Owaki et al. 2014 proved that TSPCs can produce scaffold-free tendon-like micro tissue (Owaki et al. 2014). This could be a powerful new approach for tendon tissue engineering. In chondogenesis, MSC pellet culture models are vastly used in vitro as well as implanted in vivo. MSCs are first condensed by centrifugation to form a pellet that in the presence of TGF-ßand additional molecular factors undergo in the course of approximately 3 weeks into chondrogenesis, thus replicating key assets of embryonic cartilage formation (Mueller et al. 2013; Mueller et al. 2010). In tenogenesis, the so called cell sheet technology has been preferred (Markway et al. 2013). Cell sheets can eliminate the need for natural or synthetic carriers, thus avoiding the above listed disadvantages, as well as biocompatibility (Lui et al. 2014). A cartoon model of cell sheet formation is depicted in Fig. 3. Following cell seeding and upon reaching full confluency cells establish strong cell-to-cell contacts and produce large amounts of native ECM in their apical proximity. This allows an easy dissociation from the culture dish as a continuous integral cell layer. The layer can then be rolled up and subjected to static tension for a desired period of time. In Table 3, we have provided examples of studies dealing with cell sheets for tendon tissue engineering and their outcomes. The cell sheet technology can deliver cells to tendon and tendon-bone interface to accelerate tendon healing (Inagaki et al. 2013). One research group reported the use of anterior cruciate ligament (ACL)-derived CD34+ cell sheet that was wrapped around a tendon graft for ACL reconstruction in a rat model and concluded that the cell sheet augmented graft resulted in improved and developed a more mature bone-tendon healing (Mifune et al. 2013). One study transplanted TSPC sheets in a patellar tendon window injury model and reported that 2-6 weeks post-surgery the tendon healing was significantly promoted (Lui et al. 2014). Another study indicated that the use of a graft composed of multipotent stem cell sheets led to satisfactory reconstruction of complete musculotendinous junction rupture (Inagaki et al. 2013). Komatsu et al., 2016 proved that TSPC sheets significantly improved histological properties and collagen content at both 2 and 4 weeks after implantation into a rat Achilles tendon

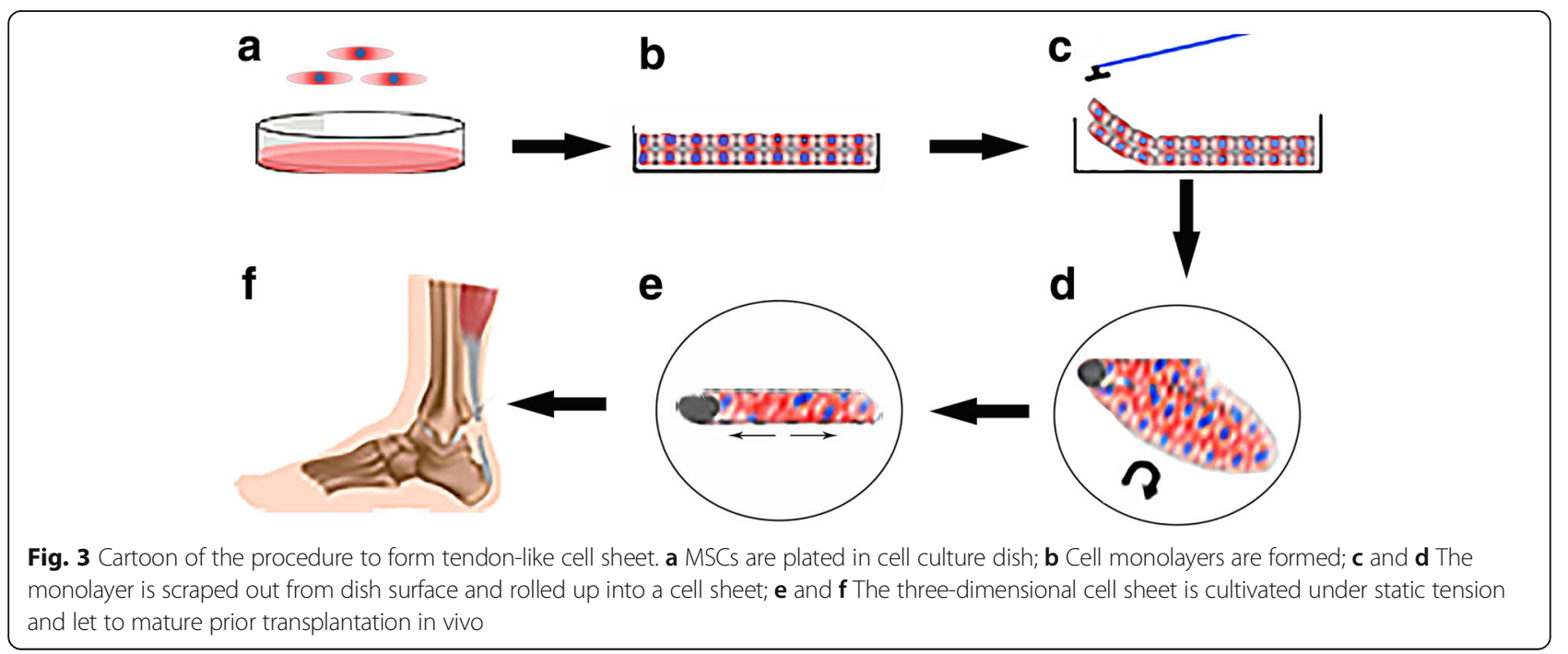


Table 3 Examples of tendon cell sheet models

\begin{tabular}{|c|c|c|c|c|}
\hline $\begin{array}{l}\text { Experimental } \\
\text { cell sheet }\end{array}$ & Outcome & Preparation of cell sheet & $\begin{array}{l}\text { Study type and } \\
\text { animal models }\end{array}$ & Reference \\
\hline $\begin{array}{l}\text { Rabbit ADSCs } \\
\text { sheet }\end{array}$ & $\begin{array}{l}\text { Cell sheets were cultured over } 3 \text { weeks, and cell } \\
\text { metabolic activity, cell sheet thickness, and early } \\
\text { differentiation gene expression were analyzed. } \\
\text { One week-old cell sheets displayed upregulation } \\
\text { of early differentiation gene markers (Runx and } \\
\text { Sox9). Cell sheet thickness and cell metabolic } \\
\text { activity increased in the second and third week. }\end{array}$ & $\begin{array}{l}\text { ADSCs were cultured in 6-well culture plates } \\
\text { until 100\% confluence. Confluent cells were then } \\
\text { cultured in expansion medium supplemented } \\
\text { with } 50 \mathrm{mg} / \mathrm{ml} \text { ascorbic acid for } 3 \text { weeks to } \\
\text { facilitate cell sheet formation. }\end{array}$ & In vitro & $\begin{array}{l}\text { Neo } \\
\text { et al. } 2016\end{array}$ \\
\hline $\begin{array}{l}\text { Mouse MSC } \\
\text { sheet }\end{array}$ & $\begin{array}{l}\text { MSC sheet transplantation into musculotendinous } \\
\text { junction at 4-8 weeks showed similar recovery of } \\
\text { muscle mass and tension to the contralateral } \\
\text { non-transplanted side. However, at 14-18 weeks, } \\
\text { MSC sheet-treated group showed increased } \\
\text { recovery of muscle mass and tension output. } \\
\text { Engrafted MSCs primarily formed connective } \\
\text { tissues and muscle fibres, and bridged the } \\
\text { ruptured tendon-muscle fibre units. }\end{array}$ & $\begin{array}{l}\text { The cells reached full confluence, detached } \\
\text { from culture dishes with } 2 \text { mM EDTA, then } \\
\text { collected and centrifuged into hybrid sheet/ } \\
\text { pellet like structure. }\end{array}$ & $\begin{array}{l}\text { In vitro and in vivo; } \\
\text { Mouse musculo- } \\
\text { tendinous junction } \\
\text { model }\end{array}$ & $\begin{array}{l}\text { Hashimotc } \\
\text { et al. } 2016\end{array}$ \\
\hline $\begin{array}{l}\text { Human ACL- } \\
\text { derived CD34 } \\
+ \text { cell sheet }\end{array}$ & $\begin{array}{l}\mathrm{ACL} \text {-derived } \mathrm{CD} 34+\text { cell sheet improved the } \mathrm{ACL} \\
\text { repair which was judged by histological } \\
\text { assessment at week } 2 \text { and biomechanical } \\
\text { evaluation at week } 8 \text { in a rat } A C L \text { injury model. }\end{array}$ & $\begin{array}{l}\text { Cells were plated in temperature-responsive } \\
\text { culture dishes at } 37^{\circ} \mathrm{C} \text { for } 17 \mathrm{~h} \text {, and then } \\
\text { incubated at } 20^{\circ} \mathrm{C} \text { for } 20 \mathrm{~min} \text {, and afterwards } \\
\text { the cell sheets detached spontaneously. }\end{array}$ & $\begin{array}{l}\text { Rat } A C L \text { injury } \\
\text { model }\end{array}$ & $\begin{array}{l}\text { Mifune } \\
\text { et al. } 2013\end{array}$ \\
\hline $\begin{array}{l}\text { Human } \\
\text { rotator cuff- } \\
\text { derived cell } \\
\text { sheet }\end{array}$ & $\begin{array}{l}\text { The cell sheets transplanted to the infraspinatus } \\
\text { injury site induced angiogenesis and Col } \\
\text { synthesis, and improved tendon-bone junction } \\
\text { repair at } 4 \text { and } 8 \text { weeks postoperation. }\end{array}$ & $\begin{array}{l}\text { Cells were cultured on } 24 \text {-well temperature- } \\
\text { responsive culture dishes at } 37^{\circ} \mathrm{C} \text { for } 17 \mathrm{~h} \text {. Then, } \\
\text { the plates were placed at room temperature for } \\
20 \text { min, and the cell sheets detached from the } \\
\text { wells spontaneously. }\end{array}$ & $\begin{array}{l}\text { Rat rotator cuff } \\
\text { injury model }\end{array}$ & $\begin{array}{l}\text { Harada } \\
\text { et al. } 2017\end{array}$ \\
\hline $\begin{array}{l}\text { Rat TSPC } \\
\text { GFP-labelled } \\
\text { sheet }\end{array}$ & $\begin{array}{l}\text { The TSPC sheet radiographically, histologically } \\
\text { and biomechanically improved ACL healing in } \\
\text { a rat model at week 2, } 6 \text { and } 12 \text { postoperatively. } \\
\text { GFP-labelled TSPCs were detected at the graft- } \\
\text { bone tunnel interface and in the intra-articular } \\
\text { graft midsubstance in all samples at week } 2 \text {. }\end{array}$ & $\begin{array}{l}\text { Cells were plated in normal culture dishes in } \\
\text { low-glucose medium. After 100\% confluence, } \\
\text { cell sheet was detached by rinsing with saline. }\end{array}$ & $\begin{array}{l}\text { Rat } A C L \text { injury } \\
\text { model }\end{array}$ & $\begin{array}{l}\text { Lui } \\
\text { et al. } 2014\end{array}$ \\
\hline $\begin{array}{l}\text { Rat TSPC } \\
\text { sheet }\end{array}$ & $\begin{array}{l}\text { TSPC sheet grafting into Achilles tendon defect } \\
\text { significantly improved the histological features } \\
\text { and Col content both at } 2 \text { and } 4 \text { weeks post- } \\
\text { surgery, indicating that TSPC sheets can speed } \\
\text { up tendon remodelling in the early stages of } \\
\text { the healing process. }\end{array}$ & $\begin{array}{l}\text { TSPC sheets were prepared by plating on } \\
\text { temperature-responsive culture dishes. Cells } \\
\text { were cultured for } 3 \text { days and then induced for } \\
\text { cell sheet formation by treating with } 25 \mathrm{mM} \text { as } \\
\text { corbic acid in complete culture medium at } \\
37^{\circ} \mathrm{C} \text {. After } 9 \text { days, monolayer cell sheets were } \\
\text { obtained by reducing the temperature from } \\
37^{\circ} \mathrm{C} \text { to } 20^{\circ} \mathrm{C} \text { for } 20 \mathrm{~min} \text {. }\end{array}$ & $\begin{array}{l}\text { Rat Achilles tendon } \\
\text { injury model }\end{array}$ & $\begin{array}{l}\text { Komatsu, } \\
\text { et al. } 2016\end{array}$ \\
\hline
\end{tabular}

injury model, indicating that such an approach may effectively promote the early stages of tendon healing (Komatsu et al. 2016). One clear advantage of the cell sheet technology is the formation of native cell-to-cell and cell-to-matrix interactions which initiate the appropriate and inherent cell signalling cascades of the used cell types (Hashimoto et al. 2016; Mifune et al. 2013; Neo et al. 2016). Further application of growth factors, media supplements affecting the cell anabolism or mechanical stimuli can further boost the effectiveness of the cell sheet maturation towards enhanced in vitro tenogenesis (Tan et al. 2012; Violini et al. 2009). Follow up research is required to optimize the current protocols. For example as reported in Table 3, at present different protocols are used to form the cell sheets and there is not only one standard technique, thus further warranting investigations to optimize the cell sheet procedure. Another point for improvement is to find strategies to augment the mechanical properties of the cell sheet grafts prior to implantation in vitro which is mainly dependant on produced ECM amount and maturity level, as well as on the graft dimensions.

\section{Conclusion}

From hard scaffolds to gel-based and scaffold-free approaches, tendon tissue engineering has significantly progressed in recent years. The improved understanding of tissue resident adult stem cells, such as BMSCs, ADSCs and TSPCs, has been very helpful and a large number of studies have clarified the advantages and disadvantages of these cell types. Growth factors steering stem cell fate toward the tenogenic lineage have been identified and overall, the protocols for in vitro tenogenesis have been improved. Still, the field needs to consider a multifactorial approach that is based on the combination and fine-tuning of chemical and biomechanical 
stimuli in order to obtain optimal tenogenesis in vitro and in vivo. The field also has to move out of a 'one size fits all' strategy for treating tendon injuries and consider that different tendon defects can be treated by 'custom design' combination of cells and carriers and personalised physiotherapy. In particular, carrier-free and gelbased applications, in combination with autologous cells, can be very attractive option to enhance conservative treated tendon injuries as they can be delivered with minimal invasive operation procedure and may lead to quicker and better outcome. All in all, tendon tissue engineering has now excellent foundations and enters the period of precision and translation to models with clinical relevance and we think undoubtedly it will remain the most promising step forward for better treatment of tendon injuries.

\begin{abstract}
Abbreviations
ACL: Anterior cruciate ligament; ADSC: Adipose-derived stem cell; BMP: Bone morphogenetic protein; BMSC: Bone marrow stem cell; CTGF: Connective tissue growth factor; ECM: Extracellular matrix; ESCs: Equine embryo-derived stem cells; FGF: Fibroblast growth factor; F-mod: Fibromodulin; GDF: Growth differentiation factor; GFP: Green fluorescence protein; HA: Hyaluronic acid; IGF: Insulin growth like factor; PCL: Poly-caprolactone; PDGF: Platelet-derived growth factor; PGA: Polyglycolic acid; PLA: Polylactic acid; PLGA: Poly-D,Llactic-co-glycolic acid; PLLA: Poly-L-lactid acid; PRP: Platelet rich plasma; PU: Polyuria; Scx: Scleraxis; TEC: Tissue-engineering construct; TGF$\beta$ : Transforming growth factor beta; TnC: Tenascin C; Tnmd: Tenomodulin TSPC: Tendon stem progenitor cell; VEGF: Vascular endothelial growth factor
\end{abstract}

\section{Acknowledgements}

D.D. acknowledges the following foundations DFG, AO and BFS for the support of tendon-related research over the years. Z.Y. and H.Y. receive PhD stipend ships by Jining Medical College Affiliated Hospital, Jining, China and China Scholarship Council, Beijing, China, correspondingly. We thank Dr. G. Pattappa for English proof-reading.

\section{Funding}

No funding was received for this study.

\section{Authors' contributions}

All authors contributed to the conception and writing of the present study and agreed on the order of authorship prior to manuscript submission. All authors read and approved the final manuscript.

\section{Ethics approval and consent to participate}

Not applicable

\section{Consent for publication}

Not applicable

\section{Competing interests}

All authors declare that they have no competing interests.

\section{Publisher's Note}

Springer Nature remains neutral with regard to jurisdictional claims in published maps and institutional affiliations.

Received: 29 September 2017 Accepted: 20 December 2017 Published online: 05 January 2018

\section{References}

Abbah SA, Spanoudes K, O'Brien T, Pandit A, Zeugolis DI (2014) Assessment of stem cell carriers for tendon tissue engineering in pre-clinical models. Stem Cell Res Ther 5(2):38
Andres BM, Murrell GA (2008) Treatment of tendinopathy: what works, what does not, and what is on the horizon. Clin Orthop Relat Res 466(7):1539-1554

Annabi N, Tamayol A, Uquillas JA, Akbari M, Bertassoni LE, Cha C, Camci-Unal G, Dokmeci MR, Peppas NA, Khademhosseini A (2014) 25th anniversary article: rational design and applications of hydrogels in regenerative medicine. Adv Mater 26(1):85-123

Aslan H, Kimelman-Bleich N, Pelled G, Gazit D (2008) Molecular targets for tendon neoformation. J Clin Invest 118(2):439-444

Bagnaninchi PO, Yang Y, El Haj AJ, Maffulli N (2007) Tissue engineering for tendon repair. Br J Sports Med 41(8):e10 discussion e10

Barsby T, Bavin EP, Guest DJ (2014) Three-dimensional culture and transforming growth factor beta3 synergistically promote tenogenic differentiation of equine embryo-derived stem cells. Tissue Eng Part A 20(19-20):2604-2613

Bi Y, Ehirchiou D, Kilts TM, Inkson CA, Embree MC, Sonoyama W, Li L, Leet Al, Seo BM, Zhang L, Shi S, Young MF (2007) Identification of tendon stem/ progenitor cells and the role of the extracellular matrix in their niche. Nat Med 13(10):1219-1227

Bian L, Guvendiren M, Mauck RL, Burdick JA (2013) Hydrogels that mimic developmentally relevant matrix and N-cadherin interactions enhance MSC chondrogenesis. Proc Natl Acad Sci U S A 110(25):10117-10122

Branford OA, Klass BR, Grobbelaar AO, Rolfe KJ (2014) The growth factors involved in flexor tendon repair and adhesion formation. J Hand Surg Eur 39(1):60-70

Breidenbach AP, Dyment NA, Lu Y, Rao M, Shearn JT, Rowe DW, Kadler KE, Butler DL (2015) Fibrin gels exhibit improved biological, structural, and mechanical properties compared with collagen gels in cell-based tendon tissueengineered constructs. Tissue Eng Part A 21(3-4):438-450

Butler DL, Juncosa-Melvin N, Boivin GP, Galloway MT, Shearn JT, Gooch C, Awad $H$ (2008) Functional tissue engineering for tendon repair: a multidisciplinary strategy using mesenchymal stem cells, bioscaffolds, and mechanical stimulation. J Orthop Res 26(1):1-9

Chen JL, Yin Z, Shen WL, Chen X, Heng BC, Zou XH, Ouyang HW (2010) Efficacy of hESC-MSCs in knitted silk-collagen scaffold for tendon tissue engineering and their roles. Biomaterials 31(36):9438-9451

Chiou GJ, Crowe C, McGoldrick R, Hui K, Pham H, Chang J (2015) Optimization of an injectable tendon hydrogel: the effects of platelet-rich plasma and adipose-derived stem cells on tendon healing in vivo. Tissue Eng Part A 21(9-10):1579-1586

da Silva ML, Fontes AM, Covas DT, Caplan Al (2009) Mechanisms involved in the therapeutic properties of mesenchymal stem cells. Cytokine Growth Factor Rev 20(5):419-427

Dai L, Hu X, Zhang X, Zhu J, Zhang J, Fu X, Duan X, Ao Y, Zhou C (2015) Different tenogenic differentiation capacities of different mesenchymal stem cells in the presence of BMP-12. J Transl Med 13:200

Degen RM, Carbone A, Carballo C, Zong J, Chen T, Lebaschi A, Ying L, Deng XH, Rodeo SA (2016) The effect of purified human bone marrow-derived Mesenchymal stem cells on rotator cuff tendon healing in an Athymic rat. Arthroscopy 32(12):2435-2443

Deng D, Wang W, Wang B, Zhang P, Zhou G, Zhang WJ, Cao Y, Liu W (2014) Repair of Achilles tendon defect with autologous ASCs engineered tendon in a rabbit model. Biomaterials 35(31):8801-8809

Dex S, Lin D, Shukunami C, Docheva D (2016) Tenogenic modulating insider factor: systematic assessment on the functions of tenomodulin gene. Gene 587(1):1-17

Docheva D, Muller SA, Majewski M, Evans CH (2015) Biologics for tendon repair. Adv Drug Deliv Rev 84:222-239

Evans RB (2012) Managing the injured tendon: current concepts. J Hand Ther 25(2):173-189 quiz 190

Fan MR, Gong M, Da LC, Bai L, Li XQ, Chen KF, Li-Ling J, Yang ZM, Xie HQ (2014) Tissue engineered esophagus scaffold constructed with porcine small intestinal submucosa and synthetic polymers. Biomed Mater 9(1):015012

Farnebo S, Woon CY, Schmitt T, Joubert LM, Kim M, Pham H, Chang J (2014) Design and characterization of an injectable tendon hydrogel: a novel scaffold for guided tissue regeneration in the musculoskeletal system. Tissue Eng Part A 20(9-10):1550-1561

Garg T, Singh O, Arora S, Murthy R (2012) Scaffold: a novel carrier for cell and drug delivery. Crit Rev Ther Drug Carrier Syst 29(1):1-63

Halper $J$ (2014) Advances in the use of growth factors for treatment of disorders of soft tissues. Adv Exp Med Biol 802:59-76

Han P, Cui Q, Yang S, Wang H, Gao P, Li Z (2017) Tumor necrosis factor-alpha and transforming growth factor-beta1 facilitate differentiation and proliferation of tendon-derived stem cells in vitro. Biotechnol Lett 39(5):711-719 
Harada Y, Mifune Y, Inui A, Sakata R, Muto T, Takase F, Ueda Y, Kataoka T, Kokubu T, Kuroda R (2017) Rotator cuff repair using cell sheets derived from human rotator cuff in a rat model. Journal of orthopaedic research : official publication of the Orthopaedic Research Society 35(2):289-296

Hashimoto H, Tamaki T, Hirata M, Uchiyama Y, Sato M, Mochida J (2016) Reconstitution of the complete rupture in musculotendinous junction using skeletal muscle-derived multipotent stem cell sheet-pellets as a "bio-bond". PeerJ 4:e2231

Hofmann A, Ritz U, Verrier S, Eglin D, Alini M, Fuchs S, Kirkpatrick CJ, Rommens PM (2008) The effect of human osteoblasts on proliferation and neo-vessel formation of human umbilical vein endothelial cells in a long-term 3D coculture on polyurethane scaffolds. Biomaterials 29(31):4217-4226

Hsieh CF, Alberton P, Loffredo-Verde E, Volkmer E, Pietschmann M, Muller P, Schieker M, Docheva D (2016a) Scaffold-free Scleraxis-programmed tendon progenitors aid in significantly enhanced repair of full-size Achilles tendon rupture. Nanomedicine (Lond) 11(9):1153-1167

Hsieh CF, Alberton P, Loffredo-Verde E, Volkmer E, Pietschmann M, Muller PE, Schieker M, Docheva D (2016b) Periodontal ligament cells as alternative source for cell-based therapy of tendon injuries: in vivo study of full-size Achilles tendon defect in a rat model. Eur cells Mater 32:228-240

Inagaki $Y$, Uematsu K, Akahane M, Morita Y, Ogawa M, Ueha T, Shimizu T, Kura T, Kawate K, Tanaka Y (2013) Osteogenic matrix cell sheet transplantation enhances early tendon graft to bone tunnel healing in rabbits. Biomed Res Int 2013:842192

Isaac C, Gharaibeh B, Witt M, Wright VJ, Huard J (2012) Biologic approaches to enhance rotator cuff healing after injury. J Shoulder Elb Surg 21(2):181-190

James R, Kesturu G, Balian G, Chhabra AB (2008) Tendon: biology, biomechanics, repair, growth factors, and evolving treatment options. J Hand Surg Am 33(1):102-112

Jiang D, Gao P, Zhang Y, Yang S (2016) Combined effects of engineered tendon matrix and GDF-6 on bone marrow mesenchymal stem cell-based tendon regeneration. Biotechnol Lett 38(5):885-892

Kim SH, Turnbull J, Guimond S (2011) Extracellular matrix and cell signalling: the dynamic cooperation of integrin, proteoglycan and growth factor receptor. J Endocrinol 209(2):139-151

Kohler J, Popov C, Klotz B, Alberton P, Prall WC, Haasters F, Muller-Deubert S, Ebert R, Klein-Hitpass L, Jakob F, Schieker M, Docheva D (2013) Uncovering the cellular and molecular changes in tendon stem/progenitor cells attributed to tendon aging and degeneration. Aging Cell 12(6):988-999

Komatsu I, Wang JH, Iwasaki K, Shimizu T, Okano T (2016) The effect of tendon stem/progenitor cell (TSC) sheet on the early tendon healing in a rat Achilles tendon injury model. Acta Biomater 42:136-146

Li S, Ma K, Li H, Jiang J, Chen S (2016) The effect of sodium hyaluronate on Ligamentation and biomechanical property of tendon in repair of Achilles tendon defect with polyethylene Terephthalate artificial ligament: a rabbit tendon repair model. Biomed Res Int 2016:8684231

Liu CF, Aschbacher-Smith L, Barthelery NJ, Dyment N, Butler D, Wylie C (2011) What we should know before using tissue engineering techniques to repair injured tendons: a developmental biology perspective. Tissue Eng Part B Rev 17(3):165-176

Liu Y, Ramanath HS, Wang DA (2008) Tendon tissue engineering using scaffold enhancing strategies. Trends Biotechnol 26(4):201-209

Liu Y, Skardal A, Shu XZ, Prestwich GD (2008) Prevention of peritendinous adhesions using a hyaluronan-derived hydrogel film following partialthickness flexor tendon injury. J Orthop Res 26(4):562-569

Lopiz Y, Arvinius C, Garcia-Fernandez C, Rodriquez-Bobada MC, Gonzalez-Lopez P, Civantos A, Marco F (2017) Repair of rotator cuff injuries using different composites. Rev Esp Cir Ortop Traumatol 61(1):51-62

Lui PP, Wong OT, Lee YW (2014) Application of tendon-derived stem cell sheet for the promotion of graft healing in anterior cruciate ligament reconstruction. Am J Sports Med 42(3):681-689

Lui PP, Wong OT, Lee YW (2016) Transplantation of tendon-derived stem cells pre-treated with connective tissue growth factor and ascorbic acid in vitro promoted better tendon repair in a patellar tendon window injury rat model. Cytotherapy 18(1):99-112

Markway BD, Cho H, Johnstone B (2013) Hypoxia promotes redifferentiation and suppresses markers of hypertrophy and degeneration in both healthy and osteoarthritic chondrocytes. Arthritis Res Ther 15(4):R92

Mifune Y, Matsumoto T, Takayama K, Terada S, Sekiya N, Kuroda R, Kurosaka M, Fu FH, Huard J (2013) Tendon graft revitalization using adult anterior cruciate ligament $(\mathrm{ACL})$-derived $\mathrm{CD} 34+$ cell sheets for $\mathrm{ACL}$ reconstruction. Biomaterials 34(22):5476-5487
Montgomery SR, Petrigliano FA, Gamradt SC (2012) Failed rotator cuff surgery, evaluation and decision making. Clin Sports Med 31(4):693-712

Mueller MB, Blunk T, Appel B, Maschke A, Goepferich A, Zellner J, Englert C, Prantl $L$, Kujat R, Nerlich M, Angele $P$ (2013) Insulin is essential for in vitro chondrogenesis of mesenchymal progenitor cells and influences chondrogenesis in a dose-dependent manner. Int Orthop 37(1):153-158

Mueller MB, Fischer M, Zellner J, Berner A, Dienstknecht T, Prantl L, Kujat R, Nerlich M, Tuan RS, Angele P (2010) Hypertrophy in mesenchymal stem cell chondrogenesis: effect of TGF-beta isoforms and chondrogenic conditioning. Cells Tissues Organs 192(3):158-166

Myer C, Fowler JR (2016) Flexor tendon repair: healing, biomechanics, and suture configurations. Orthop Clin North Am 47(1):219-226

Neo PY, See EY, Toh SL, Goh JC (2016) Temporal profiling of the growth and multi-lineage potentiality of adipose tissue-derived mesenchymal stem cells cell-sheets. J Tissue Eng Regen Med 10(7):564-579

Ni M, Rui YF, Tan Q, Liu Y, Xu LL, Chan KM, Wang Y, Li G (2013) Engineered scaffold-free tendon tissue produced by tendon-derived stem cells. Biomaterials 34(8):2024-2037

Nixon AJ, Watts AE, Schnabel LV (2012) Cell- and gene-based approaches to tendon regeneration. J Shoulder Elb Surg 21(2):278-294

Nourissat G, Berenbaum F, Duprez D (2015) Tendon injury: from biology to tendon repair. Nat Rev Rheumatol 11(4):223-233

Oryan A, Alidadi S, Moshiri A, Maffulli N (2014) Bone regenerative medicine: classic options, novel strategies, and future directions. J Orthop Surg Res 9(1):18

Owaki T, Shimizu T, Yamato M, Okano T (2014) Cell sheet engineering for regenerative medicine: current challenges and strategies. Biotechnol J 9(7): 904-914

Park A, Hogan MV, Kesturu GS, James R, Balian G, Chhabra AB (2010) Adiposederived mesenchymal stem cells treated with growth differentiation factor-5 express tendon-specific markers. Tissue Eng Part A 16(9):2941-2951

Raikin SM, Garras DN, Krapchev PV (2013) Achilles tendon injuries in a United States population. Foot Ankle Int 34(4):475-480

Ricchetti ET, Aurora A, lannotti JP, Derwin KA (2012) Scaffold devices for rotator cuff repair. J Shoulder Elb Surg 21(2):251-265

Sahoo S, Ang LT, Cho-Hong Goh J, Toh SL (2010) Bioactive nanofibers for fibroblastic differentiation of mesenchymal precursor cells for ligament/ tendon tissue engineering applications. Differentiation 79(2):102-110

Sahoo S, Toh SL, Goh JC (2010b) A bFGF-releasing silk/PLGA-based biohybrid scaffold for ligament/tendon tissue engineering using mesenchymal progenitor cells. Biomaterials 31(11):2990-2998

Sahoo S, Toh SL, Goh JC (2010c) PLGA nanofiber-coated silk microfibrous scaffold for connective tissue engineering. J Biomed Mater Res B Appl Biomater 95(1): $19-28$

Sander EA, Barocas VH, Tranquillo RT (2011) Initial fiber alignment pattern alters extracellular matrix synthesis in fibroblast-populated fibrin gel cruciforms and correlates with predicted tension. Ann Biomed Eng 39(2):714-729

Sayegh ET, Sandy JD, Virk MS, Romeo AA, Wysocki RW, Galante JO, Trella KJ, Plaas A, Wang VM (2015) Recent scientific advances towards the development of tendon healing strategies. Curr Tissue Eng 4(2):128-143

September AV, Schwellnus MP, Collins M (2007) Tendon and ligament injuries: the genetic component. Br J Sports Med 41(4):241-246 discussion 246

Shah S, Federoff HJ (2011) Therapeutic potential of vaccines for Alzheimer's disease. Immunotherapy 3(2):287-298

Tan SL, Ahmad RE, Ahmad TS, Merican AM, Abbas AA, Ng WM, Kamarul T (2012) Effect of growth differentiation factor 5 on the proliferation and tenogenic differentiation potential of human mesenchymal stem cells in vitro. Cells Tissues Organs 196(4):325-338

Thangarajah T, Pendegrass CJ, Shahbazi S, Lambert S, Alexander S, Blunn GW (2015) Augmentation of rotator cuff repair with soft tissue scaffolds. Orthop J Sports Med 3(6):2325967115587495

Thomopoulos S, Parks WC, Rifkin DB, Derwin KA (2015) Mechanisms of tendon injury and repair. J Orthop Res 33(6):832-839

Tokunaga T, Shukunami C, Okamoto N, Taniwaki T, Oka K, Sakamoto H, Ide J, Mizuta H, Hiraki Y (2015) FGF-2 stimulates the growth of Tenogenic progenitor cells to facilitate the generation of Tenomodulin-positive Tenocytes in a rat rotator cuff healing model. Am J Sports Med 43(10):2411-2422

Turner NJ, Badylak SF (2013) Biologic scaffolds for musculotendinous tissue repair Eur Cell Mater 25:130-143

Violini S, Ramelli P, Pisani LF, Gorni C, Mariani P (2009) Horse bone marrow mesenchymal stem cells express embryo stem cell markers and show the ability for tenogenic differentiation by in vitro exposure to BMP-12. BMC Cell Biol 10:29 
Voleti PB, Buckley MR, Soslowsky L (2012) Tendon healing: repair and regeneration. Annu Rev Biomed Eng 14:47-71

Woon CY, Pridgen BC, Kraus A, Bari S, Pham H, Chang J (2011) Optimization of human tendon tissue engineering: peracetic acid oxidation for enhanced reseeding of acellularized intrasynovial tendon. Plast Reconstr Surg 127(3): $1107-1117$

Wu F, Nerlich M, Docheva D (2017) Tendon injuries: basic science and new repair proposals. EFORT Open Rev 2(7):332-342

Xu Y, Dong S, Zhou Q, Mo X, Song L, Hou T, Wu J, Li S, Li Y, Li P, Gan Y, Xu J (2014) The effect of mechanical stimulation on the maturation of TDSCspoly(L-lactide-co-e-caprolactone)/collagen scaffold constructs for tendon tissue engineering. Biomaterials 35(9):2760-2772

Yamada T, Gotoh M, Nakama K, Mitsui Y, Higuchi F, Nagata K (2007) Effects of hyaluronan on cell proliferation and mRNA expression of procollagens alpha 1 (I) and alpha 1 (III) in tendon-derived fibroblasts from patients with rotator cuff disease: an in vitro study. Am J Sports Med 35(11):1870-1876

Yin $H$, Wang Y, Sun Z, Sun X, Xu Y, Li P, Meng H, Yu X, Xiao B, Fan T, Wang Y, Xu W, Wang A, Guo Q, Peng J, Lu S (2016) Induction of mesenchymal stem cell chondrogenic differentiation and functional cartilage microtissue formation for in vivo cartilage regeneration by cartilage extracellular matrix-derived particles. Acta Biomater 33:96-109

Yin Z, Chen X, Chen JL, Shen WL, Hieu Nguyen TM, Gao L, Ouyang HW (2010) The regulation of tendon stem cell differentiation by the alignment of nanofibers. Biomaterials 31(8):2163-2175

Yin Z, Chen X, Zhu T, Hu JJ, Song HX, Shen WL, Jiang LY, Heng BC, Ji JF, Ouyang HW (2013) The effect of decellularized matrices on human tendon stem/progenitor cell differentiation and tendon repair. Acta Biomater 9(12):9317-9329

Yin Z, Guo J, Wu TY, Chen X, Xu LL, Lin SE, Sun YX, Chan KM, Ouyang H, Li G (2016) Stepwise differentiation of Mesenchymal stem cells augments tendon-like tissue formation and defect repair in vivo. Stem Cells Transl Med 5(8):1106-1116

Youngstrom DW, Barrett JG (2016) Engineering tendon: scaffolds, bioreactors, and models of regeneration. Stem Cells Int 2016:3919030

Zarychta-Wisniewska W, Burdzinska A, Kulesza A, Gala K, Kaleta B, Zielniok K Siennicka K, Sabat M, Paczek L (2017) Bmp-12 activates tenogenic pathway in human adipose stem cells and affects their immunomodulatory and secretory properties. BMC Cell Biol 18(1):13

Zhao C, Chieh HF, Bakri K, Ikeda J, Sun YL, Moran SL, An KN, Amadio PC (2009) The effects of bone marrow stromal cell transplants on tendon healing in vitro. Med Eng Phys 31(10):1271-1275

\section{Submit your manuscript to a SpringerOpen ${ }^{\circ}$ journal and benefit from:}

- Convenient online submission

- Rigorous peer review

- Open access: articles freely available online

- High visibility within the field

- Retaining the copyright to your article

Submit your next manuscript at $\boldsymbol{s p r i n g e r o p e n . c o m ~}$ 